Article

\title{
Combination of Models to Generate the First PAR Maps for Spain
}

\author{
Francisco Ferrera-Cobos ${ }^{1, *(\mathbb{D})}$, Jose M. Vindel ${ }^{1}$ (D), Ousmane Wane ${ }^{1,2,3} \mathbb{D}$, Ana A. Navarro ${ }^{1}$, Luis F. Zarzalejo ${ }^{1}$ \\ and Rita X. Valenzuela ${ }^{1}$
}

Citation: Ferrera-Cobos, F.; Vindel, J.M.; Wane, O.; Navarro, A.A.;

Zarzalejo, L.F.; Valenzuela, R.X

Combination of Models to Generate the First PAR Maps for Spain. Remote Sens. 2021, 13, 4950. https:// doi.org $/ 10.3390 /$ rs13234950

Academic Editors: Liangcun Jiang, Peng Yue and Lei Hu

Received: 29 October 2021

Accepted: 30 November 2021

Published: 6 December 2021

Publisher's Note: MDPI stays neutral with regard to jurisdictional claims in published maps and institutional affiliations.

Copyright: (C) 2021 by the authors Licensee MDPI, Basel, Switzerland. This article is an open access article distributed under the terms and conditions of the Creative Commons Attribution (CC BY) license (https:// creativecommons.org/licenses/by/ $4.0 /)$
1 CIEMAT Energy Department, Renewable Energy Division, Avda. Complutense 40, 28040 Madrid, Spain; josemaria.vindel@ciemat.es (J.M.V.); Ousmane.Wane@externos.ciemat.es (O.W.); a.navarro@ciemat.es (A.A.N.); lf.zarzalejo@ciemat.es (L.F.Z.); r.valenzuela@ciemat.es (R.X.V.)

2 Department of Microbial and Plant Biotechnology, Centro de Investigaciones Biológicas Margarita Salas-CSIC, 28040 Madrid, Spain

3 E.T.S.I. Agronómica, Alimentaria y de Biosistemas, Universidad Politécnica de Madrid, 28040 Madrid, Spain

* Correspondence: francisco.ferrera@ciemat.es; Tel.: +34-91-346-6496

\begin{abstract}
This work addresses the development of a PAR model in the entire territory of mainland Spain. Thus, a specific model is developed for each location of the study field. The new PAR model consists of a combination of the estimates of two previous models that had unequal performances in different climates. In fact, one of them showed better results with Mediterranean climate, whereas the other obtained better results under oceanic climate. Interestingly, the new PAR model showed similar performance when validated at seven stations in mainland Spain with Mediterranean or oceanic climate. Furthermore, all validation slopes ranged from 0.99 to 1.00; the intercepts were less than $3.70 \mu \mathrm{mol} \mathrm{m}^{-2} \mathrm{~s}^{-1}$; the $\mathrm{R}^{2}$ were greater than 0.988 , while MBE was closer to zero percent than $-0.39 \%$; and RMSE were less than $6.21 \%$. The estimates of the PAR model introduced in this work were then used to develop PAR maps over mainland Spain that represent daily PAR averages of each month and a full year at all locations in the study field.
\end{abstract}

Keywords: photosynthetically active radiation; PAR; modeling; maps

\section{Introduction}

Photosynthetically active radiation (PAR) is the portion of the solar spectrum that ranges from 400 to $700 \mathrm{~nm}$ [1,2]. This range corresponds to the wavelengths that plants use to perform photosynthesis. In recent years, there has been a growing interest in measuring this variable due to its numerous applications in different fields of study, such as calculations involving gross primary production (GPP) or terrestrial net primary production (NPP) [3,4]. PAR is also an important variable for estimating the growth of biomass and microalgae [5-11]. Another example of PAR use is that when designing or choosing a greenhouse cover, the optical properties of the cover in the PAR range must be taken into account $[12,13]$. Therefore, PAR is an interesting variable when assessing the potential growth of a crop or when determining, in terms of agricultural productivity, which is the most suitable place.

Radiometric stations that provide PAR measurements are scarce and not always available at the required location. Thus, PAR estimates provided by satellite products. such as the Climate Monitoring Satellite Facility (CM-SAF) and the Moderate Resolution Imaging Spectroradiometer (MODIS). or by empirical models, are often used. For example, some authors have used Kato bands [14] to develop PAR models [15,16]. Others have developed multilinear PAR models that include global horizontal irradiance (GHI), global extraterrestrial irradiance, air temperature, relative humidity, clearness index, skylight brightness, solar elevation angle, solar zenith angle, dew point temperature, aerosol optical depth, air mass, total ozone column, total precipitable water, water vapor pressure, or 
saturation water vapor pressure as input variables [17-26]. Non-linear PAR models [27-29] have also been carried out in previous works.

The variability of solar irradiance and the spatial and temporal variability of the PAR/GHI ratio have previously been addressed [17,30-32]. Solar irradiance depends on cloudiness and the presence of aerosols [33]. According to Ångström's law [34], the extinction of irradiance due to aerosols is higher for shorter wavelengths. Therefore, the ultraviolet and visible bands are the bands most affected by the presence of aerosols [35]. Consequently, PAR models are highly dependent on the climatic and atmospheric conditions in which they were developed. Therefore, PAR models only obtain accurate estimates in locations where the climate and atmospheric conditions are similar to those in which they were developed.

The present work focuses in PAR modeling in Spain. Previous studies have addressed this topic $[17-19,36,37]$. The main climates present in mainland Spain according to the Köppen-Geiger classification [38-41] are oceanic varieties in northern and northwestern Spain, Mediterranean varieties in central, eastern and southern areas, arid climates in the southeast, and mountainous climates in the main mountain ranges of the Iberian Peninsula.

In a previous study [17], two PAR models for mainland Spain were developed using two different datasets; the first model was developed using the estimates provided by CMSAF, while the second was developed using the data set supplied by MODIS. According to [17], the results of the model that used CM-SAF estimates for its development were better in the Mediterranean and arid areas. By contrast, the best results in the oceanic areas were obtained with the model developed from the MODIS estimates.

In the present work, a new daily PAR model is presented that covers mainland Spain. This new model is developed using a linear combination of the estimates provided by the two PAR models elaborated in [17]. The model is validated at seven radiometric stations located on mainland Spain. Next, the estimates supplied by the new model are used to create the first monthly and annual PAR maps in mainland Spain.

This study is structured as follows. First, the data set employed and the mathematical tools used to develop the PAR model are described. Next, the results of the validation of the model with data provided by seven stations located throughout the study territory are presented. The monthly and annual PAR maps of mainland Spain developed using the estimates provided by the new PAR model are then shown. The results are discussed subsequently and, finally, the most significant conclusions are discussed.

\section{Materials and Methods}

The two models elaborated in [17] used estimates from two satellite datasets-CMSAF and MODIS- that cover the location of the Iberian Peninsula, where mainland Spain is located. The grid of both data sets ranges from $35.3^{\circ} \mathrm{N}$ to $44.0^{\circ} \mathrm{N}$ in latitude and from $9.5^{\circ} \mathrm{W}$ to $3.5^{\circ} \mathrm{E}$ in longitude. The CM-SAF grid had a resolution of $0.1^{\circ} \times 0.1^{\circ}$, while the MODIS grid had a resolution of $5 \mathrm{~km}$. In particular, the CM-SAF data set corresponded to the years 1999 to 2011 of the Spectral Resolved Irradiance (SRI) product, which belongs to the EUMETSAT Satellite Application Facility network $[42,43]$. On the other hand, the MODIS data set corresponded to the dates from 1 January 2018, to 31 May 2019 of the MCD18A1MODIS/Terra+Aqua Surface Radiation Daily/3 Hour L3 Global 5 km SIN Grid [44] and MCD18A2-MODIS/Terra+Aqua Photosynthetically Active Radiation Daily/3-Hour L3 Global $5 \mathrm{~km}$ SIN Grid [45,46] products.

Both models developed in [17] have the following mathematical structure:

$$
\mathrm{PAR}=\alpha \cdot \mathrm{GHI}+\beta
$$

where $\alpha$ and $\beta$ are specific coefficients for each point of the grid corresponding to mainland Spain. Thus, both models are valid for the whole study territory, giving specific estimates for each point.

For the present work, data from seven radiometric stations belonging to the GEOPAR Project (Project CGL2016-79284-P AEI/FEDER/UE) were used. Figure 1 shows the loca- 
tions of the stations that provided data on GHI, PAR, air temperature, and relative humidity. Further details of each station can be found in Table 1.

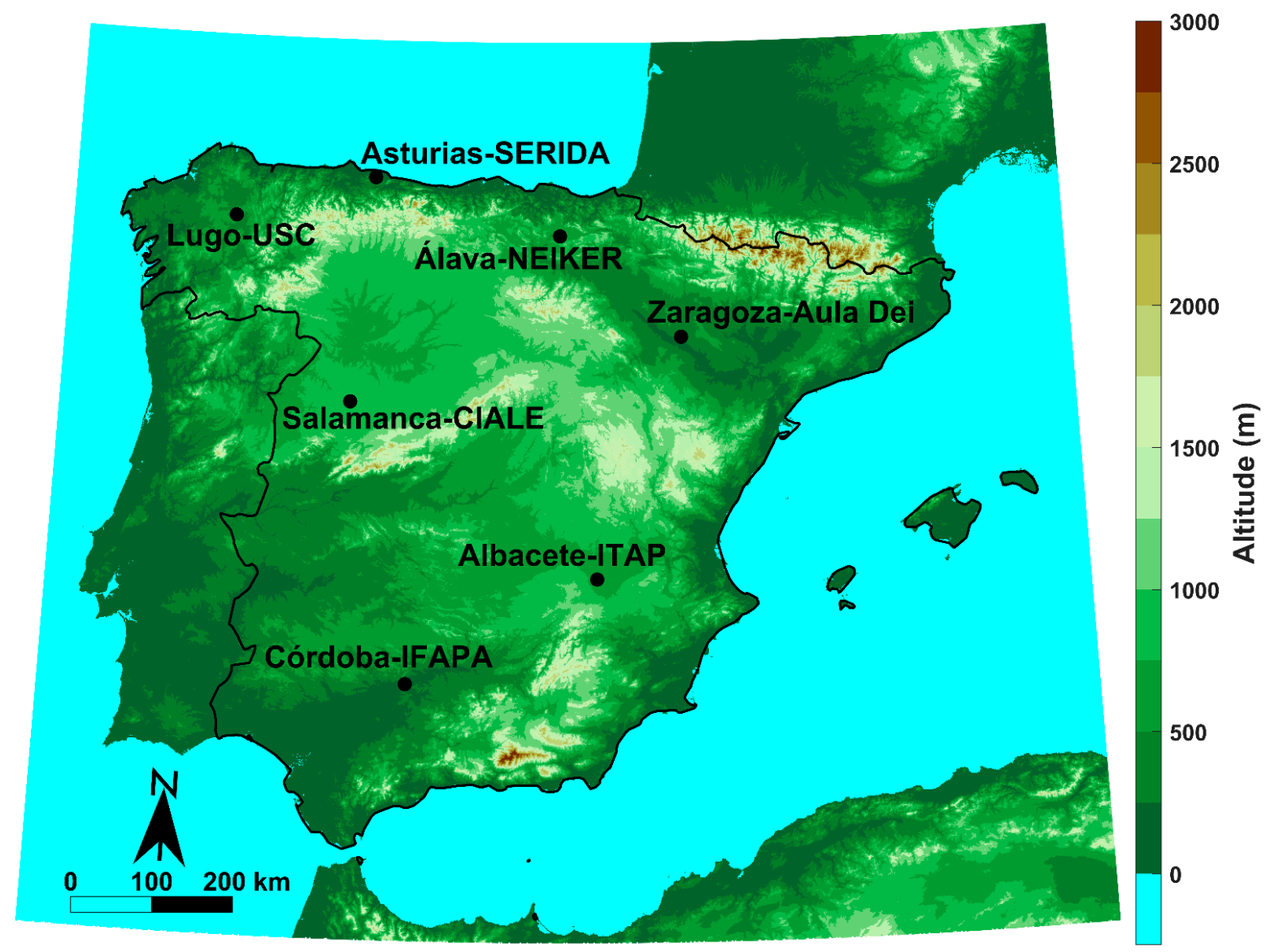

Figure 1. Location of the stations belonging to the GEOPAR project that provided the data.

Table 1. Details of the location of the seven stations belonging to the GEOPAR project. Note that the altitude is given in meters above sea level, whereas the latitude and longitude are given in degrees $\left({ }^{\circ}\right)$, where positive values indicate north and east, respectively.

\begin{tabular}{ccccc}
\hline Station & $\begin{array}{c}\text { Altitude } \\
(\mathbf{m})\end{array}$ & $\begin{array}{c}\text { Latitude } \\
\left({ }^{\circ},+\mathbf{N}\right)\end{array}$ & $\begin{array}{c}\text { Longitude } \\
\left({ }^{\circ},+\mathbf{E}\right)\end{array}$ & Climate \\
\hline Álava-NEIKER & 520 & 42.85 & -2.62 & oceanic \\
Albacete-ITAP & 698 & 39.04 & -2.08 & Mediterranean \\
Asturias-SERIDA & 6 & 43.48 & -5.44 & oceanic \\
Córdoba-IFAPA & 91 & 37.86 & -4.80 & Mediterranean \\
Lugo-USC & 447 & 43.00 & -7.54 & oceanic \\
Salamanca-CIALE & 777 & 40.98 & -5.72 & Mediterranean \\
Zaragoza-Aula Dei & 226 & 41.73 & -0.81 & Mediterranean \\
\hline
\end{tabular}

Depending on their climate, the stations can be classified into two groups: those that feature a humid climate (oceanic varieties) and those with a dry climate (Mediterranean varieties). In the first group are Álava-NEIKER, Asturias-SERIDA, and Lugo-USC. Albacete-ITAP, Córdoba-IFAPA, Salamanca-CIALE, and Zaragoza-Aula Dei belong to the second group.

As none of the GEOPAR project stations were located in the Spanish archipelagos, the study field was set to mainland Spain because the climate on the islands is quite particular and there was no way to validate the estimates of the PAR model in those places.

Daily averages of PAR and GHI data from radiometric stations were collected over a period of more than two years, specifically from 7 May 2019 to 30 June 2021. This data 
set was randomly divided into two subsets with the same number of recordings. The first subset was used to train the PAR model, whereas the second subset was used to validate the model.

To develop the PAR model, an analogous technique to that described in $[47,48]$ was applied. This methodology consisted of a linear fit between the estimates of the models developed in [17] from MODIS and CM-SAF and the measurements at the radiometric stations, as Equation (2) indicates.

$$
\text { PAR }=\mathrm{a} \cdot \mathrm{PAR}_{\text {MODIS Model }}+\mathrm{b} \cdot \mathrm{PAR}_{\mathrm{CM}-\mathrm{SAF} \text { Model }}+\mathrm{c}
$$

where the PAR MODIS Model $_{\text {is the estimates from the MODIS model, the PAR }}$ CM-SAF Model is the estimates from the CM-SAF model and $a, b$, and $c$ are the fitting coefficients.

To obtain estimates from the MODIS and CM-SAF models, the coefficients of these models were linearly interpolated to the coordinates of the location of each station and then both models were fed with the GHI data measured at the stations to calculate the PAR estimates. In this way, it is possible to obtain the coefficients $a, b$, and $c$ that correspond to each station. Therefore, the fitting coefficients obtained for the location of the stations were linearly extrapolated on a least-squares approximation of the gradient at the boundary to each location of the original data grid, in order to obtain a PAR model that covers the entire territory of mainland Spain.

To validate the new model, its estimates were compared with PAR measurements in the seven stations. Statistics such as the slope and intercept of the scatterplot between the PAR estimates and the PAR measurements, the coefficient of determination $\left(\mathrm{R}^{2}\right)$, the mean bias error (MBE) and the root mean square error (RMSE) were used to address the goodness of the models.

$$
\begin{gathered}
\text { slope }=\frac{\sum_{\mathrm{i}=1}^{\mathrm{n}}\left(\mathrm{PAR}_{\text {Model }}(\mathrm{i})-\overline{\mathrm{PAR}}_{\text {Model }}\right)\left(\mathrm{PAR}_{\text {Measured }}(\mathrm{i})-\overline{\mathrm{PAR}}_{\text {Measured }}\right)}{\sum_{\mathrm{i}=1}^{\mathrm{n}}\left(\mathrm{PAR}_{\text {Measured }}(\mathrm{i})-\overline{\mathrm{PAR}}_{\text {Measured }}\right)^{2}} \\
\text { intercept }=\overline{\mathrm{PAR}}_{\text {Model }}-\text { slope } \times \overline{\mathrm{PAR}}_{\text {Measured }} \\
\text { MBE }=\frac{1}{n} \sum_{\mathrm{i}=1}^{\mathrm{n}}\left(\operatorname{PAR}_{\text {Model }}(\mathrm{i})-\operatorname{PAR}_{\text {Measured }}(\mathrm{i})\right) \\
\text { RMSE }=\sqrt{\frac{1}{n} \sum_{\mathrm{i}=1}^{\mathrm{n}}\left(\operatorname{PAR}_{\text {Model }}(\mathrm{i})-\operatorname{PAR}_{\text {Measured }}(\mathrm{i})\right)^{2}} \\
\mathrm{R}^{2}=\frac{\sigma_{\text {ModelPAR MeasuredPAR }}^{2}}{\sigma_{\text {ModelPAR }}^{2} * \sigma_{\text {MeasurePAR }}^{2}}
\end{gathered}
$$

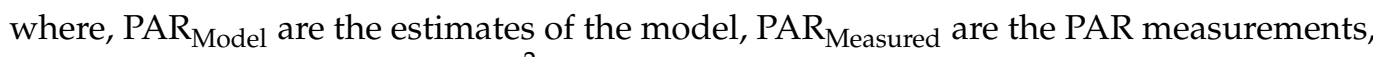
$\mathrm{n}$ is the number of recordings, $\sigma_{\text {ModelPAR MeasuredPAR }}^{2}$ is the covariance of the measured and modeled PAR, $\sigma_{\text {ModelPAR }}^{2}$ is the variance of the modeled PAR, and $\sigma_{\text {MeasurePAR }}^{2}$ is the variance of the measured PAR.

The daily PAR average of each month was then calculated using the estimates of the new model for every point of the grid corresponding to mainland Spain. Similarly, annual averages of PAR estimates were calculated. In order to make these calculations, monthly and annual averages of the CM-SAF and MODIS PAR estimates were used to feed the PAR model.

These monthly and annual PAR averages, estimated using the PAR model, were subsequently used to develop PAR maps over mainland Spain. To calculate these estimates from the PAR model estimates, it was necessary to also use estimates from the CM-SAF and MODIS datasets.

The daily data collected from the seven stations were filtered, eliminating any data that did not meet any of the following conditions. The PAR/GHI ratio (both variables in $\mathrm{W} / \mathrm{m}^{2}$ so that the ratio was dimensionless) was between 0.3 and 0.6 , relative humidity between 
0 and $100 \%$, air temperatures between -40 and $60{ }^{\circ} \mathrm{C}$, and clearness indexes $\left(\mathrm{k}_{\mathrm{t}}\right)$ between 0 and 1 . These criteria were used to discard any data recorded under environmental conditions outside the tolerance range of the instruments and to discard any data whose values do not make physical sense (for example, PAR values in $\mu \mathrm{mol} \mathrm{m}{ }^{-2} \mathrm{~s}^{-1}$ should be higher than $\mathrm{GHI}$ values in $\mathrm{W} \mathrm{m}^{-2}$ ).

\section{Results}

After applying the rejection criteria to all the data, the number of remaining records for each station is shown in Table 2.

Table 2. Number of recordings of each station before and after applying the rejection criteria.

\begin{tabular}{ccc}
\hline Station & $\begin{array}{c}\text { Number of Original } \\
\text { Recordings }\end{array}$ & $\begin{array}{c}\text { Number of Recordings } \\
\text { after Filtering }\end{array}$ \\
\hline Álava-NEIKER & 785 & 784 \\
Albacete-ITAP & 785 & 783 \\
Asturias-SERIDA & 784 & 779 \\
Córdoba-IFAPA & 785 & 784 \\
Lugo-USC & 785 & 769 \\
Salamanca-CIALE & 785 & 785 \\
Zaragoza-Aula Dei & 785 & 782 \\
\hline
\end{tabular}

Table 2 reveals that in Salamanca-CIALE, all the original recordings passed filtering. By contrast, the highest number of rejected recordings was in Lugo-USC. The number of original recordings was 785 in all stations, except in Asturias-SERIDA, where one day of data was lost.

The filtered data set for each station was randomly divided into two subsets, each containing the same number of recordings. The first subset was used to develop the PAR model, whereas the second subset was used to validate the model. The first subset was also used to calculate the estimates of the CM-SAF and MODIS models of [17] for the location of each station.

The next step was to develop the PAR model itself. Therefore, the coefficients $a$, $b$, and c were calculated for each station by multilinear fitting according to Equation (2), where the PAR estimates of the CM-SAF and MODIS models are fitted to real PAR measurements from the seven stations. Table 3 shows the fitting coefficients for each station.

Table 3. Fitting coefficients $a, b$, and $c$ for each station.

\begin{tabular}{|c|c|c|c|}
\hline Station & $\mathbf{a}$ & $\mathbf{b}$ & $c\left(\mu \mathrm{mol} \mathrm{m}{ }^{-2} s^{-1}\right)$ \\
\hline Álava-NEIKER & 0.26 & 0.79 & -9.58 \\
\hline Albacete-ITAP & -0.25 & 1.36 & -18.46 \\
\hline Asturias-SERIDA & -0.41 & 1.54 & -20.41 \\
\hline Córdoba-IFAPA & -0.09 & 1.18 & -13.89 \\
\hline Lugo-USC & 1.24 & -0.27 & -0.71 \\
\hline Salamanca-CIALE & 0.34 & 0.66 & -8.02 \\
\hline Zaragoza-Aula Dei & 0.29 & 0.79 & -9.77 \\
\hline
\end{tabular}

The fitting coefficients vary from station to station. Therefore, to develop a model that covers the entire field of study, these coefficients were linearly extrapolated to the surface of mainland Spain on a grid with a resolution of $5 \mathrm{Km}$ from $35.3^{\circ} \mathrm{N}$ to $44.0^{\circ} \mathrm{N}$ in latitude and from $9.5^{\circ} \mathrm{W}$ to $3.5^{\circ} \mathrm{E}$ in longitude. The coefficients for each point on the grid are illustrated in Figures 2-4, respectively. 


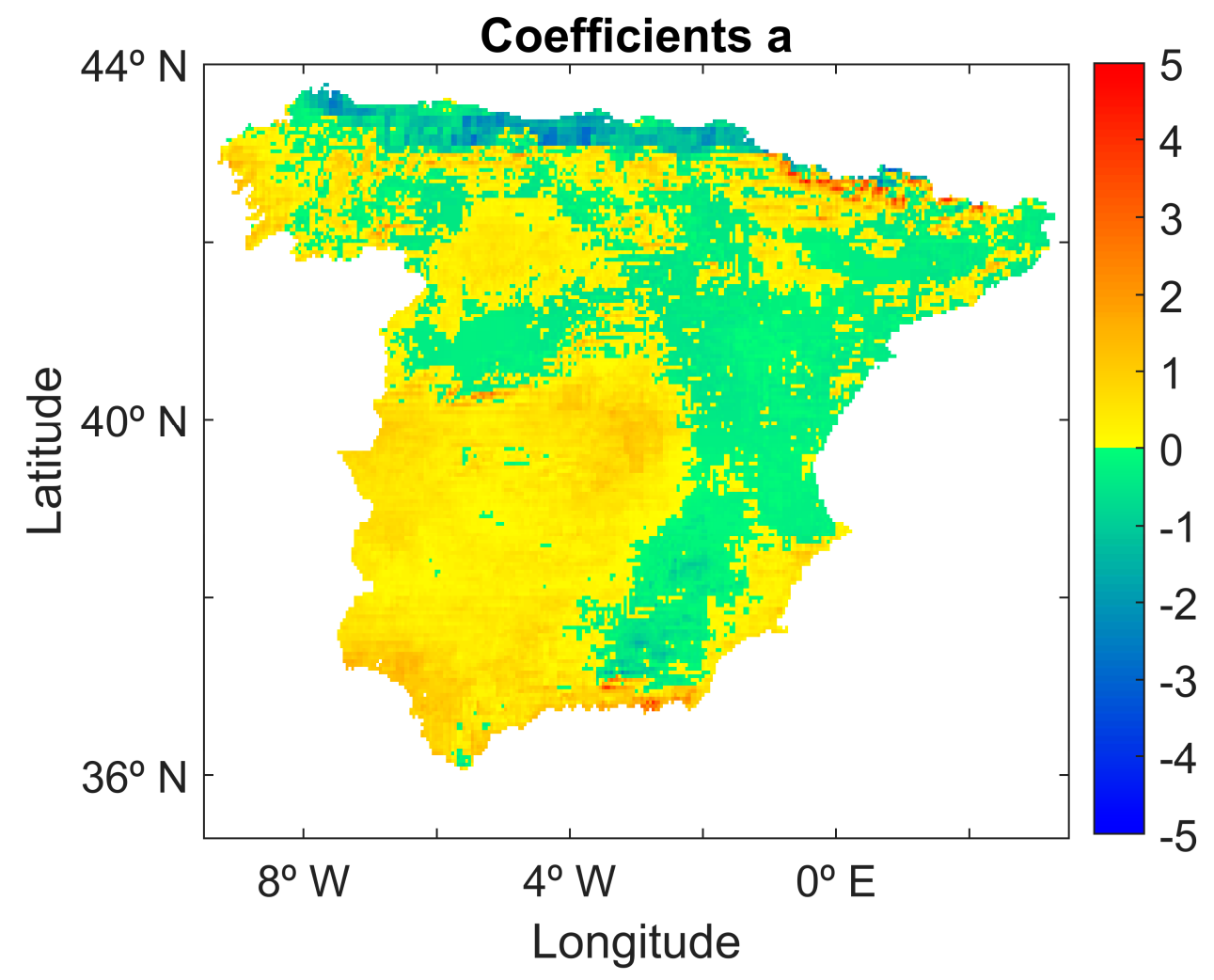

Figure 2. Coefficients a of the PAR model for each point in the study territory.

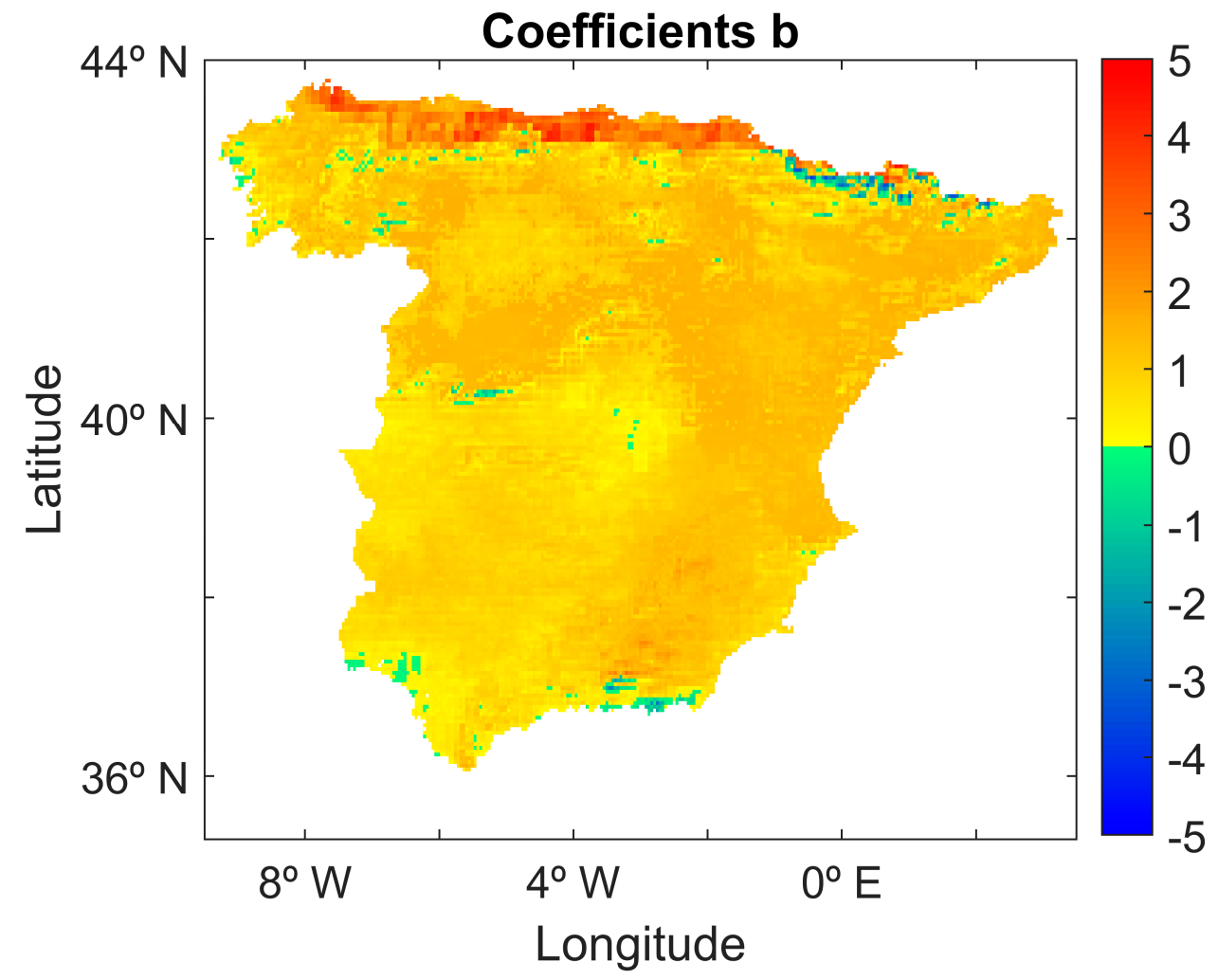

Figure 3. Coefficients $b$ of the PAR model for each point in the study territory. 


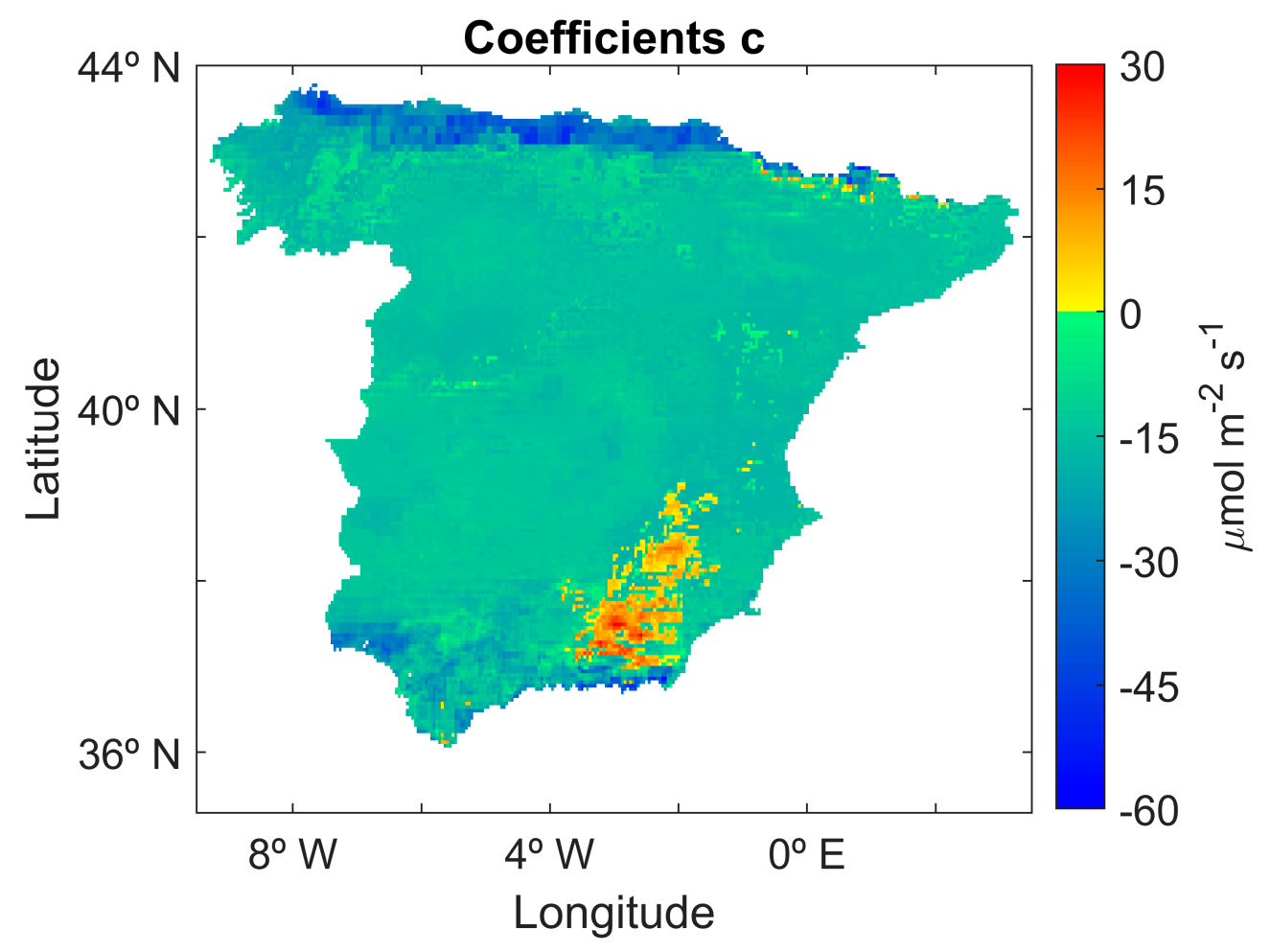

Figure 4. Coefficients $\mathrm{c}$ of the PAR model for each point in the study territory.

These coefficients needed to be validated with another data set before developing the PAR model for the entire mainland of mainland Spain. Therefore, a validation test was carried out using the validation data subset of the stations.

For this reason, the PAR estimates obtained using the validation data subset were compared to the real measurements from the stations. That is, the GHI data from the validation subset were utilized to calculate the assessments of the CM-SAF and MODIS models; then these assessments along with the corresponding coefficients $\mathrm{a}, \mathrm{b}$ and $\mathrm{c}$ were used to calculate the estimates of the new PAR model for each station. Finally, the estimates of the new PAR model were compared with the PAR data measured at each station, as illustrated by the following scatterplots. Table 4 summarizes all the validation metrics at each station.

Table 4. Summary of the validation results at each station.

\begin{tabular}{ccccccccc}
\hline & & $\begin{array}{c}\text { Álava- } \\
\text { NEIKER }\end{array}$ & $\begin{array}{c}\text { Albacete- } \\
\text { ITAP }\end{array}$ & $\begin{array}{c}\text { Asturias- } \\
\text { SERIDA }\end{array}$ & $\begin{array}{c}\text { Córdoba- } \\
\text { IFAPA }\end{array}$ & $\begin{array}{c}\text { Lugo-USC } \\
\text { Salamanca- } \\
\text { CIALE }\end{array}$ & $\begin{array}{c}\text { Zaragoza- } \\
\text { Aula } \\
\text { Dei }\end{array}$ \\
\hline & Slope & 0.99 & 1.00 & 0.99 & 1.00 & 0.99 & 0.99 & 1.00 \\
PAR model & Intercept & 2.28 & -0.07 & 1.26 & -0.55 & 1.74 & 3.70 & 1.28 \\
& $\mathrm{R}^{2}$ & 0.997 & 0.997 & 0.995 & 0.997 & 0.988 & 0.988 & 0.998 \\
& $\mathrm{MBE}$ & 0.04 & -0.39 & -0.17 & 0.10 & -0.02 & -0.38 & 0.06 \\
& $\mathrm{RMSE}$ & 3.19 & 2.54 & 4.38 & 2.47 & 6.21 & 5.71 & 2.25 \\
\hline
\end{tabular}

Figure 5 reveals the linear fit between the estimates of the PAR model and the measured PAR data, where the red line represents the linear fit. Indeed, the slope is close to the unit in all the stations, and the intercepts are close to zero, being 3.70 the highest intercept (Salamanca-CIALE). The $\mathrm{R}^{2}$ obtained is greater than 0.99 in all cases except Lugo-USC and Salamanca-CIALE, where the $\mathrm{R}^{2}$ is 0.988 . The highest RMSE values were also reached at these two stations, with $6.21 \%$ and $5.75 \%$, respectively. Regarding the MBE results, in all stations, the MBE was close to zero, $-0.39 \%$ being the highest value (Albacete-ITAP). 


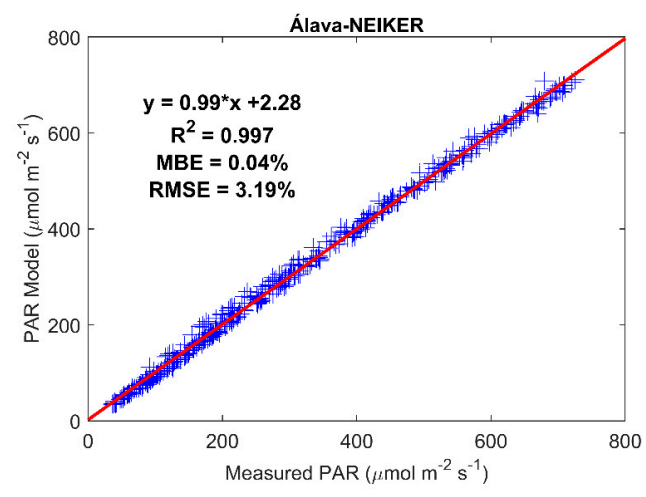

(a)

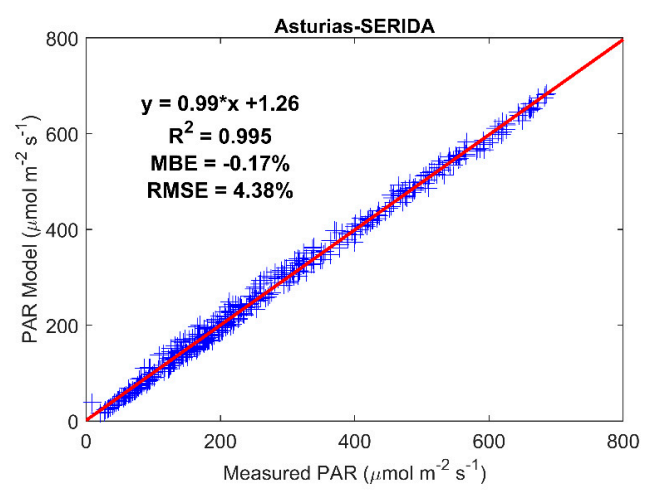

(c)

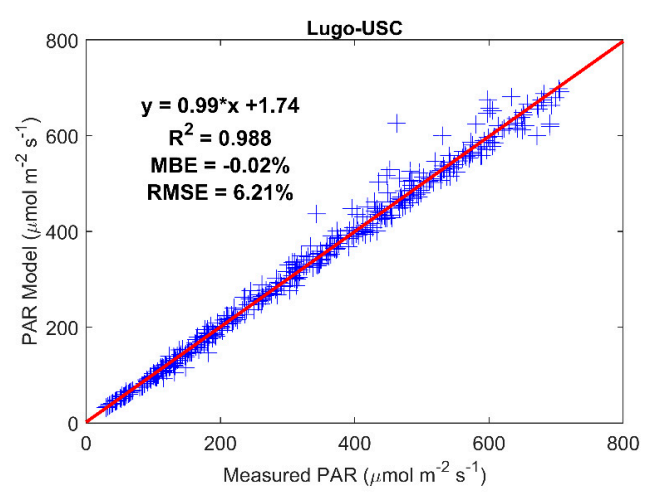

(e)

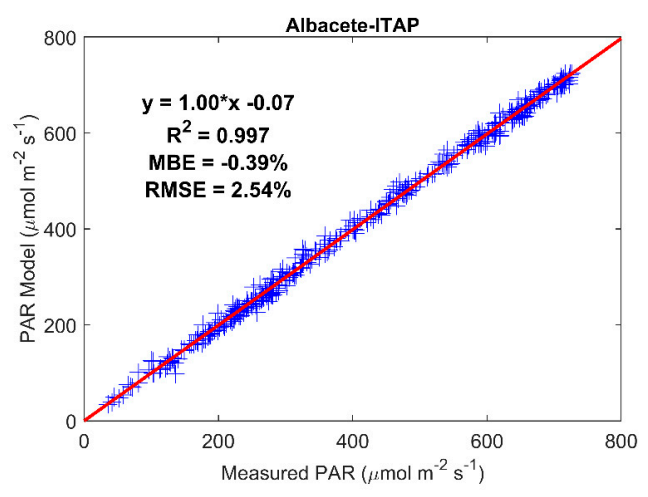

(b)

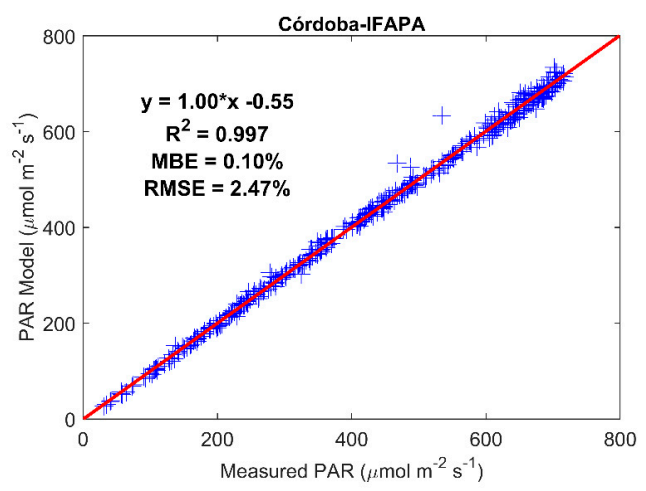

(d)

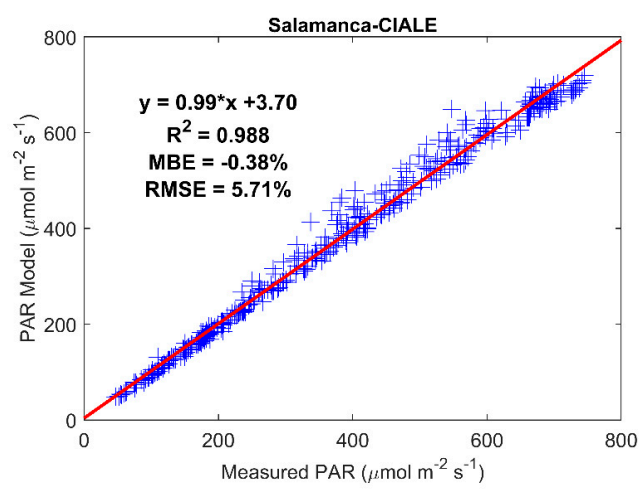

(f)

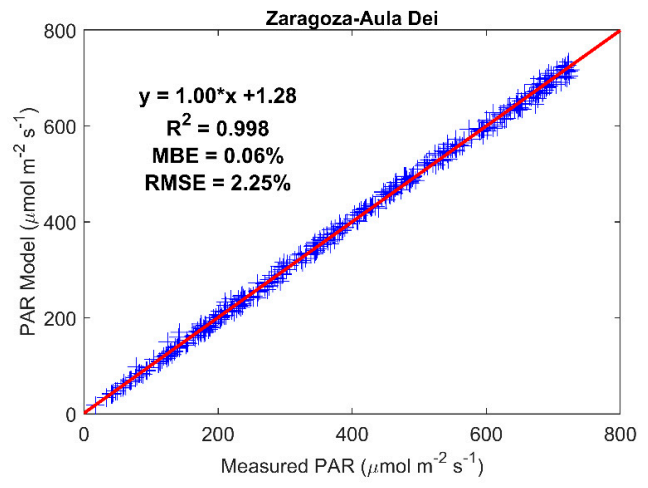

(g)

Figure 5. Validation scatterplots for each station: (a) Álava-NEIKER; (b) Albacete-ITAP; (c) Asturias-SERIDA; (d) CórdobaIFAPA; (e) Lugo-USC; (f) Salamanca-CIALE; (g) Zaragoza-Aula Dei. 


\section{Developing PAR Maps}

The PAR model developed in this study was then used to develop, for the first time, monthly and annual PAR models in mainland Spain. First, the monthly and annual averages of the daily PAR estimates were calculated using the PAR model. To do that, the monthly and annual averages of the CM-SAF and MODIS datasets were calculated. As the resolution of both datasets is different $\left(0.1^{\circ} \times 0.1^{\circ}\right.$ in the CM-SAF case and $5 \mathrm{~km} \times 5 \mathrm{~km}$ in the MODIS case), the CM-SAF grid was resized to have the same resolution in both grids. This resolution makes this model suitable to conduct generalized or large studies, but not adequate for more detailed studies. In this way, it was possible to obtain the average daily PAR estimate for each point on the grid, for every calendar month and for a year. Next, these estimates were represented on the surface of mainland Spain, as illustrated in Figures 6 and 7 .
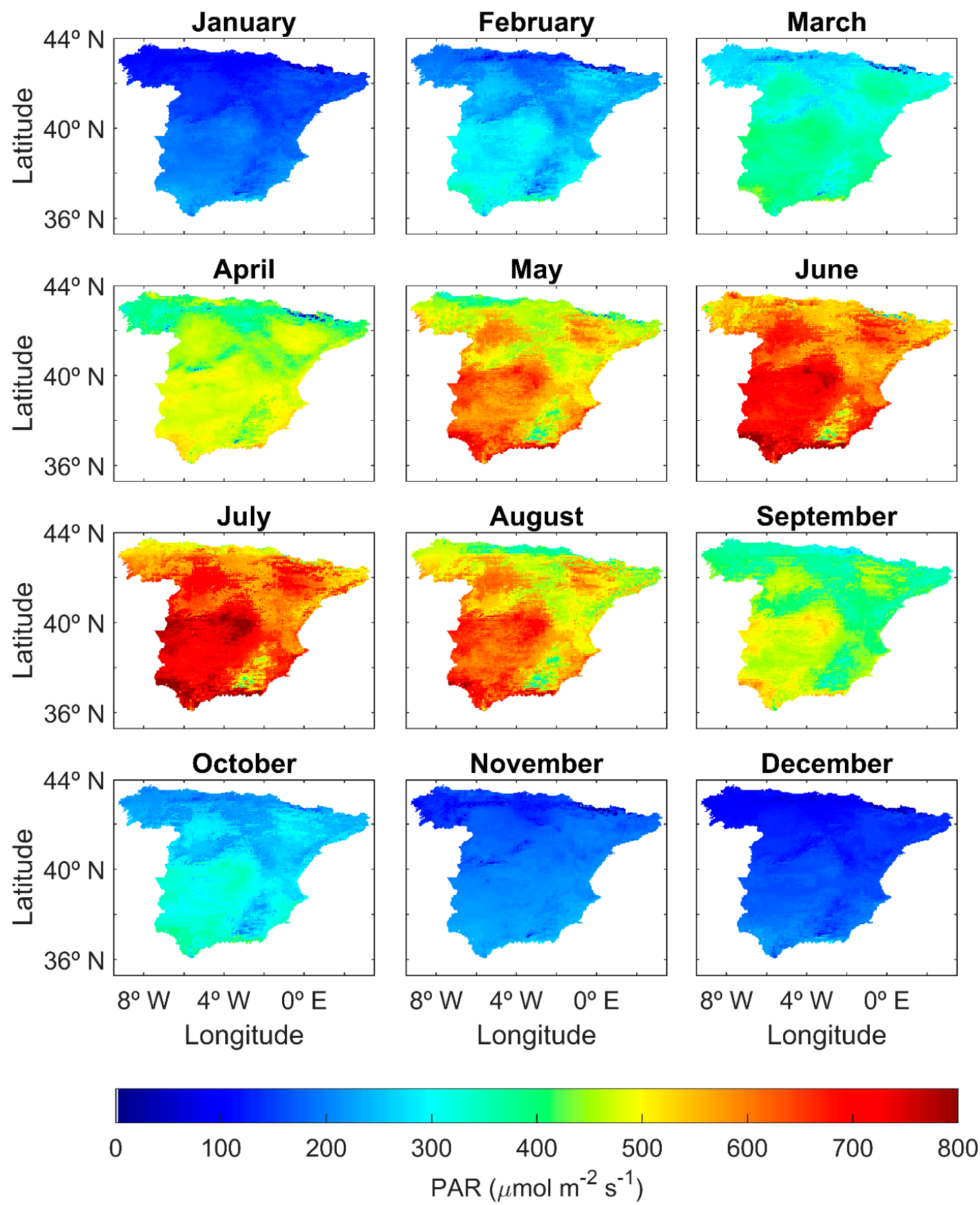

Figure 6. Daily PAR estimates for each month of the year. 


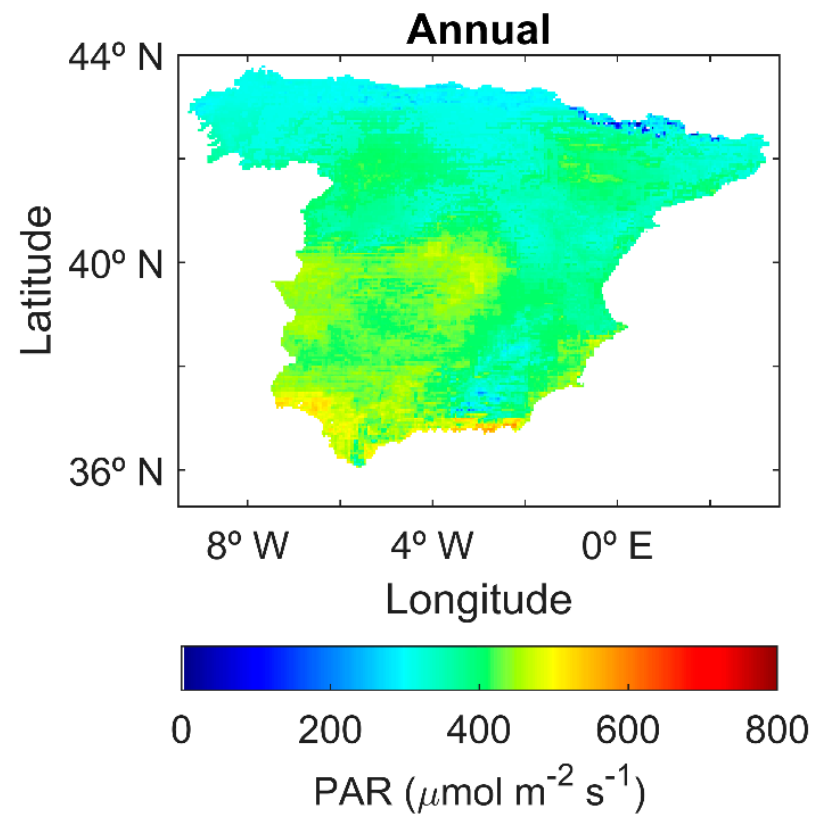

Figure 7. Daily PAR estimates for a year in mainland Spain.

\section{Discussion}

The PAR model introduced in this work has been validated in seven stations located throughout mainland Spain with different types of climate (see Table 1), according to the Köppen-Geiger classification. This model was elaborated as a linear combination of the two models developed in [17]. These two previous models exhibited different performances depending on the climate of the location. Thus, while the model developed from CM-SAF demonstrated good results in places with Mediterranean or dry climates, the model developed from MODIS obtained its better results in locations with oceanic or humid climates. The new proposed PAR model has been also compared with three models proposed by other authors [20,49].

The model proposed in [20] is described in the following equation:

$$
\mathrm{PAR}=2.242 \cdot \mathrm{GHI}
$$

Different PAR models were proposed by [49] depending of the land use of the site. One of them was developed for pasture lands and is shown in Equation (9), while the expression for forest lands is shown in Equation (10).

$$
\begin{aligned}
\mathrm{PAR} & =2.023 \cdot \mathrm{GHI}+28.557 \\
\mathrm{PAR} & =1.922 \cdot \mathrm{GHI}+3.630
\end{aligned}
$$

Table 5 illustrates the comparison between the results of the previous models and the new model, carried out with the validation data set of each station.

Comparing the slopes, the closest value to the unit was obtained with the new model at every station except at Álava-NEIKER where the closest value was obtained with Aguiar et al.'s pasture model. Likewise, the intercepts closest to zero belonged to the new model. By contrast, the results of $\mathrm{R}^{2}$ were similar to those of any of the six models. With regard to the MBE, the closest values to zero were obtained with the new model except at AlbaceteITAP and Salamanca-CIALE, where the MODIS model and the CM-SAF model obtained the closest values to zero, respectively. However, the new model obtained the lowest RMSE results at all stations. 
Table 5. Comparison between the results of the previous and new model on the seven stations. Note that the intercept is in $\mu \mathrm{mol} \mathrm{m} \mathrm{m}^{-2} \mathrm{~s}^{-1}$, while the MBE and the RMSE are both in $\%$.

\begin{tabular}{|c|c|c|c|c|c|c|c|c|}
\hline & & $\begin{array}{c}\text { Álava- } \\
\text { NEIKER }\end{array}$ & $\begin{array}{l}\text { Albacete- } \\
\text { ITAP }\end{array}$ & $\begin{array}{l}\text { Asturias- } \\
\text { SERIDA }\end{array}$ & $\begin{array}{l}\text { Córdoba- } \\
\text { IFAPA }\end{array}$ & $\begin{array}{l}\text { Lugo- } \\
\text { USC }\end{array}$ & $\begin{array}{l}\text { Salamanca- } \\
\text { CIALE }\end{array}$ & $\begin{array}{c}\text { Zaragoza-Aula } \\
\text { Dei }\end{array}$ \\
\hline \multirow{5}{*}{ CM-SAF model } & Slope & 0.93 & 0.92 & 0.91 & 0.93 & 0.94 & 0.96 & 0.89 \\
\hline & Intercept & 13.23 & 13.72 & 16.05 & 12.13 & 15.84 & 16.77 & 13.22 \\
\hline & $R^{2}$ & 0.997 & 0.997 & 0.995 & 0.997 & 0.987 & 0.987 & 0.998 \\
\hline & MBE & 3.16 & 4.72 & 3.82 & 4.34 & 1.45 & 0.13 & 7.45 \\
\hline & RMSE & 6.07 & 6.46 & 8.15 & 5.90 & 7.59 & 5.99 & 9.43 \\
\hline \multirow{5}{*}{ MODIS model } & Slope & 1.02 & 1.01 & 0.96 & 1.02 & 1.01 & 1.04 & 0.99 \\
\hline & Intercept & 2.99 & -1.60 & 6.81 & 0.71 & 6.30 & 4.14 & 1.19 \\
\hline & $\mathrm{R}^{2}$ & 0.997 & 0.996 & 0.994 & 0.997 & 0.988 & 0.987 & 0.998 \\
\hline & MBE & -2.75 & -0.25 & 1.32 & -1.91 & -2.83 & -4.63 & 0.58 \\
\hline & RMSE & 4.52 & 3.11 & 5.46 & 3.40 & 7.19 & 7.87 & 2.52 \\
\hline \multirow{5}{*}{$\begin{array}{l}\text { Escobedo et al., } \\
2009 \text { model }\end{array}$} & Slope & 1.11 & 1.10 & 1.07 & 1.10 & 1.10 & 1.13 & 1.06 \\
\hline & Intercept & 3.77 & 4.96 & 4.07 & 5.80 & 6.49 & 10.93 & 8.13 \\
\hline & $\mathrm{R}^{2}$ & 0.998 & 0.998 & 0.999 & 0.996 & 0.989 & 0.987 & 0.998 \\
\hline & MBE & 12.18 & 10.87 & 8.38 & 11.10 & 12.32 & 16.02 & 8.32 \\
\hline & RMSE & 14.12 & 11.96 & 9.79 & 12.31 & 15.64 & 18.60 & 9.26 \\
\hline \multirow{5}{*}{$\begin{array}{l}\text { Aguiar et al., } \\
2012 \text { pasture } \\
\text { model }\end{array}$} & Slope & 1.00 & 0.98 & 0.97 & 0.99 & 0.99 & 1.02 & 0.96 \\
\hline & Intercept & 31.81 & 35.05 & 31.96 & 34.60 & 35.83 & 38.17 & 36.25 \\
\hline & $R^{2}$ & 0.998 & 0.998 & 0.999 & 0.996 & 0.987 & 0.986 & 0.998 \\
\hline & MBE & 9.96 & 6.76 & 8.09 & 6.87 & 10.37 & 12.04 & 4.94 \\
\hline & RMSE & 10.30 & 7.08 & 8.62 & 7.45 & 12.42 & 13.51 & 5.82 \\
\hline \multirow{5}{*}{$\begin{array}{l}\text { Aguiar et al., } \\
2012 \text { forest } \\
\text { model }\end{array}$} & Slope & 0.95 & 0.94 & 0.92 & 0.94 & 0.94 & 0.98 & 0.91 \\
\hline & Intercept & 6.79 & 9.73 & 7.00 & 8.97 & 9.69 & 11.89 & 10.17 \\
\hline & $\mathrm{R}^{2}$ & 0.998 & 0.998 & 0.999 & 0.996 & 0.986 & 0.987 & 0.998 \\
\hline & MBE & -2.63 & -4.17 & -5.59 & -3.89 & -2.80 & 0.57 & -5.91 \\
\hline & RMSE & 4.64 & 5.41 & 7.86 & 5.32 & 8.15 & 5.91 & 7.67 \\
\hline \multirow{5}{*}{ New model } & Slope & 0.99 & 1.00 & 0.99 & 1.00 & 0.99 & 0.99 & 1.00 \\
\hline & Intercept & 2.28 & -0.07 & 1.26 & -0.55 & 1.74 & 3.70 & 1.28 \\
\hline & $R^{2}$ & 0.997 & 0.997 & 0.995 & 0.997 & 0.988 & 0.988 & 0.998 \\
\hline & MBE & 0.04 & -0.39 & -0.17 & 0.10 & -0.02 & -0.38 & 0.06 \\
\hline & RMSE & 3.19 & 2.54 & 4.38 & 2.47 & 6.21 & 5.71 & 2.25 \\
\hline
\end{tabular}

Furthermore, the results of the new model were similar at all stations: all the slopes were close to the unit; all the intercepts were close to zero, with $3.70 \mu \mathrm{mol} \mathrm{m}^{-2} \mathrm{~s}^{-1}$ being the highest value (at Salamanca-CIALE); similarly, all the MBEs were close to zero, with $-0.39 \%$ being the highest value (at Albacete-ITAP); and the highest RMSE was $6.21 \%$ (at Lugo-USC). According to these results, the new model showed no clear tendency as evaluated with these datasets and its performance was similar on every station, regardless of the climate. This result is a consequence of the combination of two previous models. One of them performed well in Mediterranean climates, while the second model obtained good results for oceanic climates.

With regard to the PAR maps, they were developed using the new PAR model introduced in this study. As expected, PAR irradiance levels increase during the summer months and decrease during the winter months. However, some trends and features remain the same every month. For example, PAR maximums are always reached in the southeast and central areas of the Iberian Peninsula along with the Guadalquivir and Ebro valleys. However, minimums of PAR irradiance were reached in northern areas of the Iberian Peninsula and mountain ranges, such as the Pyrenees, the Central Range, the Iberian Range, and the Betic Range. Furthermore, the same features are noted on the annual PAR map, where the minimums and maximums of PAR irradiance are reached in the same areas. Surprisingly, there are locations on mountain ranges, particularly in the Pyrenees in winter months, that the model significantly underestimates, producing a result near zero. 
This phenomenon could be related to the slope of the terrain as the sensors of the optical images used to obtain satellite estimates experience difficulties with the angle of incidence of the reflectance [50-52]. The presence of snow can cause underestimations as well, as it could affect the reflectance. This indicates an aspect of this PAR model that requires improvement, which may become the subject of future study.

These maps can be viewed and the PAR values for each location can be consulted at https:// par.ceta-ciemat.es/en/geopar-maps / (accesed on 15 October 2021). However, use is subject to the terms and conditions of the website.

\section{Conclusions}

A new PAR model has been introduced for Spanish territories. This new model was developed for each point of the field study from two previous models as a linear combination of their estimates. The model was validated at seven stations in Spain, four of them with Mediterranean climates and the remaining three with oceanic climates.

The most significant contribution of this study is the development of a PAR model that is suitable for any location in mainland Spain, regardless of its climate, to develop the first PAR maps over Spain. These maps graphically show daily PAR averages at all locations for each month and for the whole year.

Author Contributions: Conceptualization, J.M.V. and R.X.V.; methodology, J.M.V.; software, F.F-C.; validation, F.F.-C., J.M.V., R.X.V., A.A.N. and L.F.Z.; formal analysis, J.M.V. and F.F.-C.; investigation, R.X.V. and L.F.Z.; resources, R.X.V. and A.A.N.; data curation, F.F.-C., J.M.V., R.X.V., A.A.N., L.F.Z. and O.W.; writing-original draft preparation, F.F.-C., J.M.V., R.X.V., A.A.N., L.F.Z. and O.W.; writingreview and editing, F.F.-C., J.M.V., R.X.V., A.A.N., L.F.Z. and O.W.; visualization, R.X.V. and A.A.N.; supervision, J.M.V.; project administration, J.M.V. and R.X.V.; funding acquisition, J.M.V. and R.X.V. All authors have read and agreed to the published version of the manuscript.

Funding: The authors would like to thank the funding from the Ministry of Economy, Industry, and Competitiveness (MINECO) (Project CGL2016-79284-P AEI/FEDER/UE). FF-C acknowledges its funding to MINECO for its grant (BES-2017-082043), and also to the Autonomous Community of Madrid, Spain, and co-financed by the FEDER "A way of making Europe" ALGATEC-CM (S2018/BAA-4532) and to the CYTED-IberoAmerican Program on Science and Technology for Development (Red RENUWAL P320RT0005 CYTED).

Data Availability Statement: Figures 6 and 7 are available online at https:/ /par.ceta-ciemat.es/en/ geopar-maps / (accessed on 27 October 2021).

Acknowledgments: The authors gratefully acknowledge EPS Lugo-USC, NEIKER, Estación Experimental de Aula Dei-CSIC, CIALE-USAL, ITAP, IFAPA—Córdoba for maintaining the stations. We are also grateful for the data taken from MODIS, particularly products from NASA Level-1 and Atmosphere Archive and Distribution System (LAADS) Distributed Active Archive Center (DAAC), located in the Goddard Space Flight Center in Greenbelt, Maryland (https: / ladsweb.nascom.nasa.gov/, accessed on 27 February 2020), as well as for the SRI product of CM-SAF provided by EUMETSAT.

Conflicts of Interest: The authors declare that they have no conflict of interest.

\section{References}

1. McCree, K.J. Test of current definitions of photosynthetically active radiation against leaf photosynthesis data. Agric. Meteorol 1972, 10, 443-453. [CrossRef]

2. Ross, J.; Sulev, M. Sources of error in measurements of PAR. Agric. For. Meteorol 2000, 100, 103-125. [CrossRef]

3. Wu, C.; Niu, Z.; Tang, Q.; Huang, W.; Rivard, B.; Feng, J. Remote estimation of gross primary production in wheat using chlorophyll-related vegetation indices. Agric. For. Meteorol 2009, 149, 1015-1021. [CrossRef]

4. Pinker, R.T.; Zhao, M.; Wang, H.; Wood, E.F. Impact of satellite based PAR on estimates of terrestrial net primary productivity. Int. J. Remote Sens. 2010, 31, 5221-5237. [CrossRef]

5. Hindersin, S.; Leupold, M.; Kerner, M.; Hanelt, D. Key parameters for outdoor biomass production of Scenedesmus obliquus in solar tracked photobioreactors. J. Appl. Phycol. 2014, 26, 2315-2325. [CrossRef]

6. Raymond Hunt, E., Jr. Relationship between woody biomass and PAR conversion efficiency for estimating net primary production from NDVI. Int. J. Remote Sens. 1994, 15, 1725-1729. [CrossRef] 
7. Ramírez-Pérez, L.J.; Morales-Díaz, A.B.; De Alba-Romenus, K.; González-Morales, S.; Benavides-Mendoza, A.; Juárez-Maldonado, A. Determination of micronutrient accumulation in greenhouse cucumber crop using a modeling approach. Agronomy 2017, 7, 79. [CrossRef]

8. Kim, T.H.; Lee, Y.; Han, S.H.; Hwang, S.J. The effects of wavelength and wavelength mixing ratios on microalgae growth and nitrogen, phosphorus removal using Scenedesmus sp. for wastewater treatment. Bioresour. Technol 2013, 130, 75-80. [CrossRef]

9. Trofimchuk, O.A.; Petikar, P.V.; Turanov, S.B.; Romanenko, S.A. The influence of PAR irradiance on yield growth of Chlorella microalgae. IOP Conf. Ser. Mater. Sci. Eng. 2019, 510. Available online: https://iopscience.iop.org/article/10.1088/1757-899X/51 0/1/012017/meta (accessed on 25 November 2020). [CrossRef]

10. Schmidt, J.J.; Gagnon, G.A.; Jamieson, R.C. Microalgae growth and phosphorus uptake in wastewater under simulated cold region conditions. Ecol. Eng. 2016, 95, 588-593. [CrossRef]

11. Vadiveloo, A.; Moheimani, N.R.; Cosgrove, J.J.; Bahri, P.A.; Parlevliet, D. Effect of different light spectra on the growth and productivity of acclimated Nannochloropsis sp. (Eustigmatophyceae). Algal. Res. 2015, 8, 121-127. [CrossRef]

12. Cemek, B.; Demir, Y.; Uzun, S.; Ceyhan, V. The effects of different greenhouse covering materials on energy requirement, growth and yield of aubergine. Energy 2006, 31, 1780-1788. [CrossRef]

13. Lee, C.S.; Hoes, P.; Cóstola, D.; Hensen, J.L.M. Assessing the performance potential of climate adaptive greenhouse shells. Energy 2019, 175, 534-545. [CrossRef]

14. Kato, S.; Ackerman, T.P.; Mather, J.H.; Clothiaux, E.E. The k-distribution method and correlated-k approximation for a shortwave radiative transfer model. J. Quant. Spectrosc. Radiat. Transf. 1999, 62, 109-121. [CrossRef]

15. Wandji Nyamsi, W.; Espinar, B.; Blanc, P.; Wald, L. Estimating the photosynthetically active radiation under clear skies by means of a new approach. Adv. Sci. Res. 2015, 12, 5-10. [CrossRef]

16. Vindel, J.M.; Valenzuela, R.X.; Navarro, A.A.; Zarzalejo, L.F.; Paz-Gallardo, A.; Souto, J.; Méndez-Gómez, R.; Cartelle, D.; Casares, J. Modeling photosynthetically active radiation from satellite-derived estimations over mainland Spain. Remote Sens. 2018, 10, 849. [CrossRef]

17. Ferrera-Cobos, F.; Vindel, J.M.; Valenzuela, R.X.; González, J.A. Analysis of spatial and temporal variability of the PAR/GHI ratio and PAR modeling based on two satellite estimates. Remote Sens. 2020, 12, 1262. [CrossRef]

18. Ferrera-Cobos, F.; Vindel, J.M.; Valenzuela, R.X.; González, J.A. Models for estimating daily photosynthetically active radiation in oceanic and mediterranean climates and their improvement by site adaptation techniques. Adv. Space Res. 2020, 65, 1894-1909. [CrossRef]

19. Ferrera-Cobos, F.; Vindel, J.M.; Valenzuela, R.X. A New index assessing the viability of par application projects used to validate PAR models. Agronomy 2021, 11, 470. [CrossRef]

20. Escobedo, J.F.; Gomes, E.N.; Oliveira, A.P.; Soares, J. Modeling hourly and daily fractions of UV, PAR and NIR to global solar radiation under various sky conditions at Botucatu, Brazil. Appl. Energy 2009, 86, 299-309. [CrossRef]

21. Alados, I.; Foyo-Moreno, I.; Alados-Arboledas, L. Photosynthetically active radiation: Measurements and modelling. Agric. For. Meteorol. 1996, 78, 121-131. [CrossRef]

22. Janjai, S.; Wattan, R.; Sripradit, A. Modeling the ratio of photosynthetically active radiation to broadband global solar radiation using ground and satellite-based data in the tropics. Adv. Space Res. 2015, 56, 2356-2364. [CrossRef]

23. Mizoguchi, Y.; Yasuda, Y.; Ohtani, Y.; Watanabe, T.; Kominami, Y.; Yamanoi, K. A practical model to estimate photosynthetically active radiation using general meteorological elements in a temperate humid area and comparison among models. Theor. Appl. Climatol. 2014, 115, 583-589. [CrossRef]

24. Jacovides, C.P.; Boland, J.; Asimakopoulos, D.N.; Kaltsounides, N.A. Comparing diffuse radiation models with one predictor for partitioning incident PAR radiation into its diffuse component in the eastern Mediterranean basin. Renew. Energy 2010, 35, 1820-1827. [CrossRef]

25. Pashiardis, S.; Sa, K.; Pelengaris, A. Characteristics of photosynthetic active radiation (PAR) through statistical analysis at Larnaca, Cyprus. SM J. Biom. Biostat. 2017, 2, 1-16.

26. Yu, X.; Guo, X. Hourly photosynthetically active radiation estimation in Midwestern United States from artificial neural networks and conventional regressions models. Int. J. Biometeorol. 2016, 60, 1247-1259. [CrossRef]

27. Yu, X.; Wu, Z.; Jiang, W.; Guo, X. Predicting daily photosynthetically active radiation from global solar radiation in the Contiguous United States. Energy Convers. Manag. 2015, 89, 71-82. [CrossRef]

28. Ren, X.; He, H.; Zhang, L.; Yu, G. Estimation of diffuse photosynthetically active radiation and the spatiotemporal variation analysis in China from 1981 to 2010. J. Geogr. Sci. 2014, 24, 579-592. [CrossRef]

29. Ren, X.; He, H.; Zhang, L.; Yu, G. Global radiation, photosynthetically active radiation, and the diffuse component dataset of China, 1981-2010. Earth Syst. Sci. Data 2018, 10, 1217-1226. [CrossRef]

30. McCandless, T.C.; Haupt, S.E.; Young, G.S. A model tree approach to forecasting solar irradiance variability. Sol. Energy 2015, 120, 514-524. [CrossRef]

31. Hu, B.; Wang, Y.; Liu, G. Spatiotemporal characteristics of photosynthetically active radiation in China. J. Geophys. Res. 2007, 112, D14106. [CrossRef]

32. Pozo-Vázquez, D.; Wilbert, S.; Gueymard, C.; Alados-Arboledas, L.; Santos-Alamillos, F.; Granados-Munoz, M. Interannual variability of long time series of DNI and GHI at PSA, Spain. Proc. SolarPACES Conf. 2011, 1-8. Available online: https://www. 
researchgate.net/publication/225023716_Interannual_Variability_of_long_time_series_of_DNI_and_GHI_at_PSA_Spain (accessed on 25 May 2018).

33. Xia, X.; Li, Z.; Wang, P.; Chen, H.; Cribb, M. Estimation of aerosol effects on surface irradiance based on measurements and radiative transfer model simulations in northern China. J. Geophys. Res. 2007, 112, D22S10. [CrossRef]

34. Ångström, A. On the atmospheric transmission of sun radiation and on dust in the air. Geogr. Ann. 1929, 11, 156. [CrossRef]

35. Kidder, S.Q.; Vonder Haar, T.H. Satellite Meteorology—An introduction; Academic Press: Cambridge, MA, USA, 1995; ISBN 978-0124064300.

36. Alados-Arboledas, L.; Olmo, F.J.; Alados, I.; Pérez, M. Parametric models to estimate photosynthetically active radiation in Spain. Agric. For. Meteorol. 2000, 101, 187-201. [CrossRef]

37. Foyo-Moreno, I.; Alados, I.; Alados-Arboledas, L. A new conventional regression model to estimate hourly photosynthetic photon flux density under all sky conditions. Int. J. Climatol. 2017, 37, 1067-1075. [CrossRef]

38. Köppen, W.; Geiger, R. Das geographische system der klimate. In Handbuch der Klimatologie; Gebrüder Bornträger: Berlín, Germany, 1936; p. 44.

39. Beck, H.E.; Zimmermann, N.E.; McVicar, T.R.; Vergopolan, N.; Berg, A.; Wood, E.F. Present and future Köppen-Geiger climate classification maps at 1-km resolution. Sci. Data 2018, 5, 180214. [CrossRef]

40. Peel, M.C.; Finlayson, B.L.; McMahon, T.A. Updated world map of the Köppen-Geiger climate classification. Hydrol. Earth Syst. Sci. 2007, 11, 1633-1644. [CrossRef]

41. Agencia Estatal de Meteorología (AEMET); Instituto de Meteorologia de Portugal (IM). Iberian Climate Atlas; AEMET-Ministerio de Medio Ambiente y Medio Rural y Marino \& Instituto de Meteorologia de Portugal: Madrid, Spain, 2011; ISBN 978-84-7837-079-5.

42. Müller, R.; Pfeifroth, U.; Träger-Chatterjee, C.; Cremer, R.; Trentmann, J.; Hollmann, R. Surface Solar Radiation Data Set-Heliosat (SARAH)-Edition 1. EUMETSAT Satell. Appl. Facil. Clim. Monit. 2015. Available online: https://wui.cmsaf.eu/safira/action/ viewDoiDetails?acronym $=$ SARAH_V001 (accessed on 11 December 2019). [CrossRef]

43. Schulz, J.; Albert, P.; Behr, H.-D.; Caprion, D.; Deneke, H.; Dewitte, S.; Dürr, B.; Fuchs, P.; Gratzki, A.; Hechler, P.; et al. Operational climate monitoring from space: The EUMETSAT satellite application facility on climate monitoring (CM-SAF). Atmos. Chem. Phys. 2009, 9, 1687-1709. [CrossRef]

44. Wang, D. MODIS/Terra+Aqua Surface Radiation Daily/3-Hour L3 Global 5km SIN Grid V006 [Data Set]. Available online: https: / lpdaac.usgs.gov / products / mcd18a1v006 (accessed on 10 November 2019). [CrossRef]

45. Wang, D. MODIS/Terra+Aqua Photosynthetically Active Radiation Daily/3-Hour L3 Global 5km SIN Grid V006 [Data Set]. Available online: https:/ /lpdaac.usgs.gov/products/mcd18a2v006 (accessed on 10 November 2019). [CrossRef]

46. Wang, D.; Liang, S.; Zhang, Y.; Gao, X.; Brown, M.G.L.; Jia, A. A new set of MODIS land products (MCD18): Downward shortwave radiation and photosynthetically active radiation. Remote Sens. 2020, 12, 168. [CrossRef]

47. Bernardos, A.; Gastón, M.; Fernández-Peruchena, C.; Martín, L.; Bermejo, D.; Vindel, J.M.; Ramírez, L.; Liria, J. Solar Resource Mapping in Tanzania; Solar Modeling Report; World Bank Group: Washington, DC, USA, 2015.

48. Ferrera Cobos, F. Desarrollo de una Red de Medidas y Modelización de la Radiación Fotosintéticamente Activa; Universidad Politécnica de Madrid: Madrid, Spain, 2021. [CrossRef]

49. Aguiar, L.J.G.; Fischer, G.R.; Ladle, R.J.; Malhado, A.C.M.; Justino, F.B.; Aguiar, R.G.; da Costa, J.M.N. Modeling the photosynthetically active radiation in South West Amazonia under all sky conditions. Theor. Appl. Climatol. 2012, 108, 631-640. [CrossRef]

50. Hao, D.; Wen, J.; Xiao, Q.; Wu, S.; Lin, X.; You, D.; Tang, Y. Modeling anisotropic reflectance over composite sloping terrain. IEEE Trans. Geosci. Remote Sens. 2018, 56, 3903-3923. [CrossRef]

51. Yin, G.; Li, A.; Zhao, W.; Jin, H.; Bian, J.; Wu, S. Modeling canopy reflectance over sloping terrain based on path length correction. IEEE Trans. Geosci. Remote Sens. 2017, 55, 4597-4609. [CrossRef]

52. Wen, J.; Liu, Q.; Xiao, Q.; Liu, Q.; You, D.; Hao, D.; Wu, S.; Lin, X. Characterizing land surface anisotropic reflectance over rugged terrain: A review of concepts and recent developments. Remote Sens. 2018, 10, 370. [CrossRef] 